\title{
Solar-cell technology attracts investment
}

\begin{abstract}
Pecent announcements regarding the
Rconstruction of several new photovoltaic production facilities around the globe have demonstrated that investment in the solar-energy market is still strong. JA Solar (Shanghai, China), a manufacturer of monocrystalline silicon solar cells, recently agreed to build a production plant in Hefei, China. The plant, which will have an eventual capacity of $3 \mathrm{GW}$, will begin construction this year and start production of solar cells sometime in 2012. Chinese banks and Shanghai's investment group have pledged US $\$ 2.05$ billion over the next four years for its construction.

Polysilicon Technology Company (PTC) has signed a US\$380 million engineering contract to construct a facility for producing solar-grade polysilicon in Jubail,
\end{abstract}

Saudi Arabia. The facility is expected to have an initial production capacity of 3,350 metric tons. The plan is to build the plant in three phases, ending in 2017, at a total cost of US\$1.25-1.5 billion. PTC is a joint venture between the Saudi Arabia-based Mutajadedah Energy and KCC Corporation of Seoul, South Korea.

The Indian government is in talks with Rusnano (Moscow, Russia), a state-owned nanotechnology company, to start a joint venture that will manufacture silicon ingots for use in the production of solar cells. The Russian plant could help give Indian photovoltaics manufacturers a reliable source of silicon, thereby helping to reduce fluctuations in costs. Indian officials have said they're hoping to get 2,000 tons of silicon ingots from the venture.
The US Department of Energy has guaranteed a US\$197 million loan to SoloPower (San Jose, USA) to build a plant in Wilsonville, Oregon, for the manufacturing of flexible solar cells. A $75 \mathrm{MW}$ production line is planned for completion by the end of 2011, but this will eventually be upgraded to a capacity of 400 MW. SoloPower's panels are based on copper-indium-gallium diselenide (CIGS), which has a lower efficiency than crystalline silicon cells but is less expensive to make and install, says CEO Tim Harris. CIGS panels are also around 75\% lighter than traditional solar panels. "That enables easy installation on commercial and industrial rooftops," explains Harris. "You just can't put the weight of traditional panels on many roofs."

\section{E-book display sales soar}

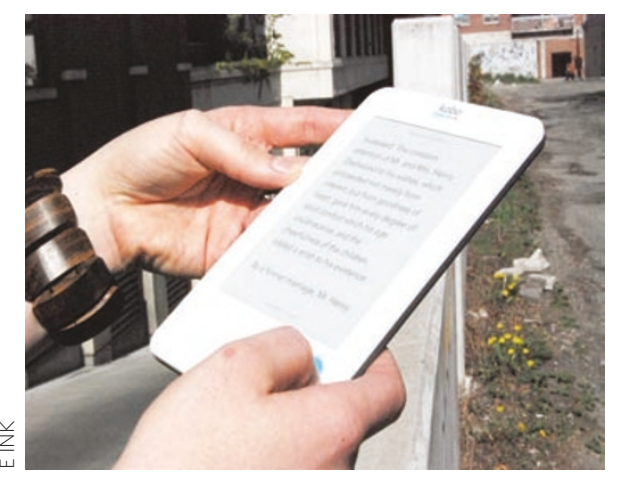

E Ink Holdings, whose power-efficient display technology is used in the Amazon Kindle as well as a range of other electronic book (e-book) readers, says sales of its products nearly doubled in the last quarter of 2010. In the quarter ending 31 December, E Ink Holdings of Hsinchu, Taiwan, reported sales of NT $\$ 9.7$ billion - up 84\% from the previous quarter and $96 \%$ from the same quarter in 2009. Overall sales for 2010 reached NT $\$ 25.2$ billion - up 57\% from the previous year. Net income for the year was NT\$4 billion, whereas in 2009 the company reported a loss. "We tripled the number of ePaper displays shipped in 2009 for the eReader market alone," said Chairman Scott Liu, when announcing the results. The company says it is now the world's largest supplier of displays to the e-book market. E Ink Holdings was created in 2009 by the merger of Taiwan's Prime View International, a manufacturer of electronic paper display modules, and E Ink Corporation (Cambridge, Massachusetts, USA), which makes electronic paper. The displays manufactured by E Ink are viewable in direct sunlight and use power only when the image is changed, thus reducing the demands placed on the e-book's battery.

\section{ITO alternative receives investment}

A start-up company developing a carbonnanotube-based ink for transparent electrodes has raised US\$3.2 million in a first round of financing. C3Nano (Hayward, California, USA) received the funding from GSR Ventures, a venture capital fund in Beijing, China, and Palo Alto in the USA. The ink developed by C3Nano can be used to make transparent electrodes and films for use with touchscreen devices, organic light-emitting diodes, photovoltaics and flexible displays. The ink is intended to be a replacement for indium tin oxide (ITO), which is widely used throughout the industry. "ITO is becoming more expensive because indium is relatively rare, whereas carbon is ubiquitous," says Zhenan Bao, a professor of chemical engineering at Stanford University in the USA and one of the founders of C3Nano. The manufacturing process consumes relatively little energy because the ink is processed in solution at moderate temperatures, explains Bao. The ink is also less brittle than ITO, making it more suited for use on flexible substrates such as plastic. The deposited film must be highly transparent while maintaining high conductivity. "We have certain treatment methods that can boost the conductivity of the deposited film," says Bao. C3Nano is working on turning her laboratory demonstration into a commercially viable process, and she hopes to have it on the market within a couple of years. Kevin Yin, a partner at GSR, says his firm wants to help C3Nano develop global partnerships, particularly in Asia, which is home to many manufacturers of displays, touch-screens and photovoltaic technologies.

\section{LED maker buys lighting company}

Osram Opto Semiconductors (Regensburg, Germany), the solid-state lighting division of Siemens, is in the process of buying Siteco Lighting (Traunreut, Germany) from Barclay's Private Equity (London, England). Siteco produces luminaires and lighting systems for both indoor and outdoor spaces such as parks, roads and public buildings, including Taipei Tower in Taiwan and Barajas Airport in Madrid, Spain. Siteco employs 1,250 people worldwide and had revenues of around $€ 220$ million in 2010 . Osram has 40,000 employees and is a major manufacturer of LEDs and organic LEDs. The market for components, luminaires and lighting systems is currently estimated to be around $€ 45$ billion, and Osram says the growing use of energy-efficient LEDs and organic LEDs will drive it to $€ 65$ billion by 2016 . 